\title{
Prawdziwa fikcja. 0 przekraczaniu granic gatunkowych w filmie dokumentalnym
}

\begin{abstract}
Mamy akwarium. Jest bardzo spokojne, śliczne falujq w nim roślinki, rybki spokojnie sobie pływaja, piaseczek jest czyściutki. Wiadomo jednak, że w tym akwarium czasami dziejq się burze. Jakaś ryba się zdenerwuje, pogryzie innq, piasek idzie do góry... Gdybym mógł z kamerq i mikrofonem być przy tym akwarium przez miesiąc, to bym takie coś złapał, ale wiem, że nie złapię. Wobec tego ja to akwarium biorę $w$ rękę i lekko nim potrząsam
\end{abstract}

Marcel Łoziński (2006)

\section{Streszczenie}

Marcel Łoziński, jeden z czołowych twórców polskiego filmu dokumentalnego, swoją autorską metodę nazwał „zagęszczaniem rzeczywistości”. Polegała ona na wprowadzeniu do filmowanego świata podstawionych przez siebie bohaterów, prowokowaniu rzeczywistości po to, by ujawnić jej charakterystyczne cechy, niewidoczne na pierwszy rzut oka bądź niedostępne dla kamery. Łoziński porównywał siebie do obserwatora akwarium, który zamiast czekać, aż coś się wydarzy, decyduje się nim potrząsnąć, wzbić piasek do góry, wywołać reakcję. Metoda Łozińskiego była jedną z pierwszych prób odejścia od kina obserwacyjnego, od metody cierpliwego oka. Współczesne kino dokumentalne coraz częściej rozwija podejście Łozińskiego i wręcz eksperymentuje z granicami gatunkowymi - tworząc kino pogranicza, filmowe hybrydy balansujące między dokumentem a fabułą.

1 Agnieszka Zwiefka-Chwałek, Wydział Filologiczny, Uniwersytet Wrocławski, Polska, e-mail: Agnieszka.Zwiefka@gmail.com, ORCID ID: https://orcid.org/0000-0003-3328-8584. 
Niniejszy artykuł jest próbą usystematyzowania tego zjawiska na polskim gruncie i wpisania go w szerszą światową tendencję, której przedstawicielem jest choćby Joshua Oppenheimer (reżyser słynnej Sceny zbrodni) nazywający swoje filmy „dokumentami wyobraźni”.

\title{
Słowa kluczowe:
}

film dokumentalny, inscenizacje, hybrydy filmowe, dokument wyobraźni

\begin{abstract}
Marcel Łoziński, one of the most important Polish documentary film directors, described his method of working as "densifying the reality". It means that the director introduces into the real world and real situations actors whose role is to provoke the reality, discover its' characteristic elements that are either invisible at first sight or unreachable to film with a camera. Łoziński compared himself to a person observing an aquarium, who instead of waiting until something happens, decides to shake the aquarium, provoke situations, cause reactions. Łoziński's method was one of the first attempts to move away from strictly observational mode of documentary cinema. Directors of contemporary documentary films more and more often develop this approach even experimenting with the borders of a genre, creating hybrid films that blur the boundaries between documentary and fiction. This article is an attempt to describe different styles of hybrid films in Poland and compare them with international tendencies, such as what Joshua Oppenheimer (the author of "The Act of Killing”) calls the "documentary of imagination".
\end{abstract}

\section{Keywords:}

documentary film, staging, hybrid films, documentary of imagination

Łoziński, jeden z czołowych twórców polskiego filmu dokumentalnego, swoją autorską metodę nazwał „zagęszczaniem rzeczywistości”. Polega ona na wprowadzeniu do filmowanego świata podstawionych przez reżysera bohaterów, prowokowaniu rzeczywistości po to, by ujawnić jej charakterystyczne cechy, niewidoczne jednak na pierwszy rzut oka bądź niedostępne dla kamery.

Skrajnym przypadkiem metody zagęszczania rzeczywistości jest film Łozińskiego Jak żyć opowiadający o PRL-owskim obozie dla młodych małżeństw a de facto będący portretem zindoktrynowanego komunistycznego społeczeństwa. Łoziński zasugerował organizatorom przeprowadzenie konkursu na wzorowe małżeństwo, stworzył jego regulamin, a między uczestników wprowadził podsta- 
wioną parę udającą niepokorne, nonkonformistyczne małżeństwo, które bardzo szybko zaczęło irytować pozostałych uczestników obozu. W efekcie zamierzonej prowokacji i wprowadzenia fikcjonalnego elementu udało się jednak zarejestrować autentyczne reakcje uczestników obozu. Dzięki wygenerowaniu sytuacji konfliktowej, zmuszającej bohaterów filmu do wyboru, reżyser tworzy metaforyczny obraz świata - można powiedzieć „świat skondensowany”, opisujący charakterystyczne cechy ludzkiego zachowania w obliczu wyzwania.

Metoda Łozińskiego była jedną z pierwszych w Polsce prób odejścia od radykalnej w swoich założeniach metody „cierpliwego oka” Kazimierza Karabasza (zgodnie z którą reżyser powinien maksymalnie ograniczyć swoją obecność, ingerencję w otaczającą rzeczywistość) czy zagranicznych filmowców spod znaku cinema verite. Jednak same źródła filmu dokumentalnego są zgoła odmienne, co widać już w pierwszej definicji filmu dokumentalnego stworzonej przez Johna Griersona w 1926 roku w odniesieniu do filmów Roberta Flaherty’ego Moana i Nanook of the North (Nanuk z Północy). Jego definicja filmu dokumentalnego jest na język polski tłumaczona jako „twórcza interpretacja rzeczywistości” (Przylipiak, 2004, s. 18). Czym jednak jest rzeczywistość i jak dalece posunięta może być jej twórcza interpretacja? Warto w tym momencie przywołać oryginalną definicję Griersona, która brzmi „creative treatment of actuality” (a nie „reality”) (Rotha, 1952, s. 70). Tym samym Grierson nie rości sobie pretensji do odzwierciedlenia rzeczywistości, a jedynie zwraca uwagę na realny (słowo actuality można przetłumaczyć jako realizm) charakter pokazywanych w filmie dokumentalnym wydarzeń - zaznaczając jednocześnie, iż jest to realizm kreatywny, a zatem dopuszczający autorski punkt widzenia, niczym filtr zniekształcający „realne” wydarzenia i interpretujący je przez pryzmat twórczej wrażliwości reżysera. Rzeczywistość w filmie dokumentalnym można zatem określić jako rzeczywistość interpretowaną, przefiltrowaną, wykreowaną.

Niejasność granic filmu dokumentalnego spowodowała, iż jako jedyny rodzaj filmowy doczekał się on oficjalnej definicji. W 1948 roku światowa organizacja World Union of Documentary sformułowała następującą definicję: „Przez film dokumentalny należy rozumieć wszelkie metody rejestrowania na taśmie filmowej rozmaitych aspektów rzeczywistości interpretowanych bądź jako faktycznie sfilmowane, bądź też jako jej wiarygodna i usprawiedliwiona rekonstrukcja” (Hendrykowski, 1995). W ten sposób granice filmu dokumentalnego zostały (zresztą nie po raz ostatni) poszerzone o paradokumentalne zdjęcia, w ramach których np. rekonstruowano wydarzenia. Tym samym otwarto drogę do fikcjonalizacji przekazu dokumentalnego, wprowadzenia w jego ramy gatunkowe zabiegów kreacyjnych, dających większą swobodę wypowiedzi artystycznej. 
Pierwsi dokumentaliści, tacy jak Robert Flaherty, rozumieli, że każdy zapis filmowy ma znamiona kreacji, nigdy nie jest pełnym odzwierciedleniem rzeczywistości. Jak powiedział Jean-Luc Godard: „Każdy montaż jest kłamstwem”. Poprzez wykorzystanie konkretnych ujęć spośród setek, tysięcy dostępnych zdecydowanie się na dominującą tonację wizualną filmu (nieraz „kolorującą” otaczającą nas rzeczywistość, nadającą jej nieobecne dotychczas odcienie), rodzaj montażu, który narzuca interpretację (choćby sekwencyjność scen, których znaczenie, a zarazem znaczenie przedstawianej w nich rzeczywistości może się znacząco różnić w zależności od miejsca w filmie), po tak oczywiste zabiegi, jak selekcja niektórych tylko wątków, niektórych wydarzeń i sytuacji z całego bogactwa świata rzeczywistego.

Inscenizacja, ingerencja w świat przedstawiony jest elementarną częścią filmów dokumentalnych - jak choćby w przypadku Nanuka z Północy Roberta Flahertiego, opowieści o życiu Eskimosa. Reżyser filmu nie tylko dobierał kostiumy głównego bohatera, które miały mieć bardziej „pierwotny” wygląd niż noszone na co dzień przez Nanuka, ale i wyposażył go w broń, z której na co dzień Eskimosi już nie korzystali, a w roli rodziny Nanuka obsadził osoby z nim nie spokrewnione, lecz najlepiej prezentujące się przed kamerą. Warto dla porządku zaznaczyć, że sam Flaherty nie uważał siebie za „dokumentalistę”.

Sięgając jeszcze bardziej wstecz, do samych początków kinematografii, inscenizację z udziałem zwyczajnych ludzi, bohaterów filmów, wykorzystywali choćby bracia Lumière, na co zwracają uwagę Mark Cousins i Kevin McDonald - autorzy Imagining Reality (Cousins, McDonald, 1996). Bracia Lumière rejestrowali sceny z życia codziennego ich najbliższego otoczenia, które nazywali „aktualnościami” i które okazały się bardzo popularne wśród publiczności i znalazły naśladowców wśród innych pionierów kina. Atrakcyjność tych nagrań według ówczesnych widzów polegała na ich spontaniczności, uwiecznianiu życia tu i teraz. Jednak, jak słusznie zwracają uwagę Cousins i McDonald, te „spontaniczne” sceny były w większości starannie inscenizowane. Grali w nich członkowie rodziny Lumière i zatrudniani przez nich pracownicy, bardzo często wcielając się w osoby, którymi naprawdę nie były, a w filmach widać nawet reakcje aktorów na sygnały zza kamery. Określenie „inscenizacja spontanicznych scen” zresztą najlepiej oddaje sprzeczność pomiędzy rzeczywistością realizacji filmu dokumentalnego a oczekiwaniami wobec niego, szczególnie tymi, które się ukształtowały w kolejnych dekadach.

Na przełomie lat 50. i 60., wraz z pojawieniem się nurtu kina bezpośredniego, zaczęto kłaść nacisk na dokument obserwacyjny, nieinscenizowany, pozbawiony komentarza, odpowiedzialność za interpretację przenoszący na widza. Ten model dokumentu obserwacyjnego tak mocno zakorzenił się w świadomości widzów jak oczekiwanie od dokumentu obiektywizmu. Mirosław Przylipiak trafnie opisuje 
to jako „wyraz prastarej ludzkiej tęsknoty za poznaniem »rzeczy samej w sobie“” (Przylipiak, 2004, s. 113). Najbliższe idei „czystej rejestracji” powinny być aspirujące do naukowych (a zatem obiektywnych) opisów filmy etnograficzne. Jednak ich twórcy od początku byli świadomi tego, że kamera zawsze zmienia zastaną sytuację, dynamikę relacji między bohaterami wydarzeń a także między bohaterami a twórcami - dlatego też za wszelką cenę podkreślali w realizowanych przez siebie filmach obecność ekipy i etnografa.

Flahertianowska tradycja dokumentalnej kreacji wydaje się jednak szczególnie aktualna we współczesnej dokumentalistyce, która po latach prymatu kina obserwacyjnego odchodzi od reżyserskiej przeźroczystości w stronę ujawniania obecności reżysera bądź wręcz jawnej krytyki dawnych metod. Avi Mograbi, jeden z czołowych współczesnych reżyserów filmów dokumentalnych, swoją metodę pracy określa jako bycie „muchą w zupie” (fly in the soup), tym samym odcinając się od dominującego przez dekady paradygmatu „muchy na ścianie” (fly on the wall), dokumentalisty, który nie ingeruje w rzeczywistość, a jedynie ją podgląda. Mucha w zupie ma wywołać niesmak, wprawić w zakłopotanie, zmusić do refleksji - nie tylko swoją treścią, ale i formą, coraz częściej odbiegającą od kina obserwacyjnego i idącą w stronę fabularyzacji. Zgodnie z tą zasadą Mograbi o konflikcie palestyńsko-izraelskim opowiada filmem ubranym w formę musicalu a Joshua Oppenheimer w Scenie zbrodni pozwala indonezyjskim zbrodniarzom inscenizować popełnione przed laty morderstwa w konwencji kina gangsterskiego, musicalu czy westernu. Obu twórców łączy przekonanie, że nieraz inscenizacja umożliwia poznanie prawdy o otaczającym nas świecie o wiele bardziej niż stricte dokumentalna rejestracja ze wszystkimi swoimi ograniczeniami, a zatem (paradoksalnie) posiada wartość dokumentalnego zapisu.

Swój film Z32 Mograbi nazywa „tragicznym musicalem dokumentalnym”. Opowiada on prawdziwą historię młodego żydowskiego żołnierza, który zabił w trakcie służby dwóch palestyńskich policjantów i opowiadając o tej historii swojej dziewczynie, szuka swego rodzaju rozgrzeszenia. Mograbi inscenizuje jego spowiedź na wzór brechtowskiej Opery za trzy grosze, włączając w film dokumentalny piosenki wykonane przez komentatora (w tej roli występuje sam Mograbi) i wprowadzające poszczególne obrazy, sceny dzieła. W kluczowych momentach filmu Mograbi całkowicie opuszcza wątek i uzupełnia opowiadaną historię muzycznie w duchu kupletów Kurta Weilla. Mograbi nie wierzy w bezstronną „obserwację”, jego kamera jest zawsze elementem zdarzeń, a on sam nie unika zamieszczania w swoich filmach deklaracji światopoglądowych czy wręcz politycznych. Może denerwować czy bulwersować, ale nie można go nie zauważyć - tak jak muchy w zupie. 
Jednym z najgłośniejszych filmów ostatnich lat była Scena zbrodni Joshuy Oppenheimera, opowieść o ludobójstwie widzianym oczyma tych, którzy go dokonali. W trakcie puczu wojskowego w Indonezji w 1965 roku organizacje paramilitarne zamordowały ponad milion ludzi podejrzewanych o komunizm. Dziś sprawcy nie tylko nie zostali rozliczeni z popełnionych przez siebie zbrodni, lecz są uprzywilejowanymi obywatelami, zapraszanymi przez media i jawnie opowiadającymi o popełnionych przez siebie zbrodniach. Przed puczem byli sprzedawcami kinowych biletów zafascynowanymi amerykańską kinematografią, zwłaszcza thrillerami, kinem akcji, klasycznymi filmami noir z lat 30. XX wieku, westernami czy musicalami. Oppenheimer postanowił wykorzystać ich fascynację kinem po to, by wspólnie z nimi odtworzyć popełniane zbrodnie w konwencji filmów, którymi tak bardzo się fascynowali. Już sama scena początkowa Sceny zbrodni pokazuje założenia tej metody. Widzimy surrealistyczną dekorację i inscenizację, w której barwnie ubrane i ucharakteryzowane postaci przez swoją mimikę próbują wyrazić ogrom szczęścia. To, co ma być spontaniczne i dobrowolne, na pierwszy rzut oka wydaje się sztuczne wykreowane. Akcja rozgrywa się na tle ogromnego wodospadu i pięknych górskich widoków, które jak wyjaśnia jeden z „aktorów” tej sceny mają symbolizować głębię ich uczuć, doniosłość przeżyć.

W filmie Oppenhaimera popkultura, zwłaszcza amerykańskie kino klasy B, odgrywa zresztą niezwykłą rolę. Staje się rodzajem catharsis. Filmowane inscenizacje morderstw reżyser potem pokazuje bohaterom. Anwar Congo, główny bohater Sceny zbrodni, oglądając inscenizację ze swoim udziałem, w pewnym momencie czuje dyskomfort. Nie przeszkadza mu, jak twierdzi - moralna okropność czynów, w których uczestniczył, ale sposób ich przedstawienia. Krytykuje sposób realizacji sceny, grę aktorską, sekwencję wydarzeń, stara się sprawić wrażenie znawcy. Według Oppenheimera Anwar Congo, oglądając nagranie, rozumie, że popełnił czyn moralnie niewybaczalny, ale nie może się do tego przyznać przed sobą samym. Film ma mu w tym pomóc.

Nie sposób, analizując film Oppenhaimera, nie odnieść się do klasycznego tekstu Edgara Morina Dusza kina, opisującego mechanizm projekcji-identyfikacji, czyli uczestnictwa uczuciowego, które odgrywa dużą rolę w naszym życiu prywatnym i społecznym, czy też do słów Gorkiego o „na wpół wyobrażeniowej rzeczywistości ludzkiej”. Zgodnie z tymi teoriami zacieramy granicę pomiędzy uczestnictwem wyobrażonym a realnym, pomiędzy spektaklem a życiem. „Wchodzenie w rolę, »ucieleśnienie« rządzą stosunkami człowieka z człowiekiem. Nasza osobowość jest czymś w rodzaju gotowizny, ready made. Nakładamy ją na siebie jak ubranie, a owo ubranie jest gotową rolą. Gramy w życiu pewną rolę i to nie tylko dla innych, ale również (i przede wszystkim) dla siebie. Kostium (to prze- 
branie), twarz (maska), słowa (konwencja), poczucie naszej ważności (ta komedia) pozwalają nam w życiu dawać przedstawienie tak dla siebie, jak dla innych: owo przedstawienie to wyobrażone projekcje-identyfikacje. (...) Kinematograf (czy też nasz wewnętrzny kinematograf wyobraźni) wykorzystuje czar obrazu, to znaczy odnawia lub uwzniośla widok rzeczy banalnych i codziennych” (Morin, 1975, s. 113-116).

Fabularyzując fragmenty swojej dokumentalnej opowieści, Oppenheimer ukazuje świat wewnętrzny swoich bohaterów, umożliwia widzowi przyjrzenie się mechanizmom, które sprawiły, że popełniali zbrodnie, traktując je jako coś równie nierzeczywistego, jak scena w filmie fabularnym. Joshua Oppenheimer tak opisuje wykorzystywaną przez siebie metodę pracy: „W swoich filmach zawsze łączyłem dokument i fikcję. Zawsze, kiedy kogoś filmujesz, kreujesz rzeczywistość. Jeżeli sfilmujesz dziecko idące pierwszy raz do szkoły, wielkim wydarzeniem w jego życiu będzie film, a nie szkoła. Wszyscy będą udawać, że kamery nie ma, ale przecież ona jest. Skoro i tak kreujemy z bohaterami rzeczywistość, wykreujmy taką, która skłania do refleksji. Gangsterzy w młodości kochali amerykańskie filmy, mieli swoich ulubionych aktorów. Anwar Congo metodę zabijania drutem podpatrzył na filmach o włoskiej mafii. Byli podekscytowani możliwością nakręcenia scen. Ja dokumentowałem proces ich powstawania. W ten sposób stworzyliśmy jakby nowy rodzaj dokumentu - dokument wyobraźni” (Oppenheimer, 2015). Dokument wyobraźni zamiast dokumentować kolejne wydarzenia z życia bohaterów, przedstawiać fakty, dokumentuje ich świat wewnętrzny, uciekając się w tym celu do środków stylistycznych właściwych filmom fabularnym.

Ta metoda pracy twórczej, sprzeciwiająca się kategorycznemu rozdzielaniu filmu dokumentalnego i fabularnego, jest dziś coraz bardziej popularna wśród współczesnych filmowców. Według Marka Hendrykowskiego „nie chodzi tu wcale o wyższość jednej metody realizacji nad drugą ani o takie czy inne przymieszki w postaci paradokumentalizmu lub fabularyzacji. Rzecz bynajmniej nie w tym, żeby widzieć fabułę i dokument oddzielnie, lecz w tym, by odkryć i na nowo uruchomić olbrzymi kreacyjny potencjał zawarty w ich biegunowym przeciwieństwie. Kino jako sztuka więdnie za każdym razem, kiedy tylko obie te dziedziny twórczości popadają w odosobnienie i gdy są traktowane jako sfery całkiem niezależne od siebie. Rozkwita zaś, ilekroć domena dokumentu i domena fikcji fabularnej zbliżają się jedna do drugiej, czerpiąc energię z wzajemnego oddziaływania i wymiany twórczych inspiracji. Można wtedy mówić o powtórnym odkrywaniu rzeczywistości przez filmowca i widza” (Hendrykowski, 2005, s. 18-19).

Filmy pogranicza, powstające na styku granicy między kinem fabularnym a dokumentalnym, niejednokrotnie ją zdecydowanie przekraczające, filmy trans- 
gresyjne, eksperymentujące są we współczesnej kinematografii najciekawszymi przykładami twórczych poszukiwań. Dobrym przykładem filmu „pomiędzy” jest obraz Pawła Łozińskiego Nawet nie wiesz, jak bardzo Cię kocham. Film Łozińskiego podzielony jest na pięć rozdziałów będących zapisem kolejnych sesji, jakie u uznanego krakowskiego psychoterapeuty, prof. Bogdana de Barbaro, odbywają Ewa i Hania - matka i córka. Obie od wielu lat trwają w niezdrowej relacji, nie potrafią się porozumieć i przy dowolnej okazji wzajemnie się ranią. Oparte na zbliżeniach zdjęcia, zawsze en face, wygaszona do minimum scenografia, wysuwają na pierwszy plan emocje bohaterek i wypowiadane słowa. Zapowiada się jak typowy film obserwacyjny, podglądający relacje niezwracających uwagi na kamerę bohaterów - jednak w rzeczywistości film Łozińskiego niewiele ma wspólnego z tak wąskim pojmowaniem dokumentalistyki. Jak się dowiadujemy z napisów końcowych - Ewa i Hania nie są rodziną, są jedynie „jakąś matką” i ,jakąś córką”, a ich terapie z udziałem prof. de Barbaro zostały zainscenizowane. Reżyser zdecydował się na taki krok z kilku powodów - jednym z nich, tym najbardziej banalnym, ale jakże często ograniczającym poznanie otaczającego nas świata przy metodach stricte obserwacyjnych, jest brak możliwości filmowania, w tym przypadku brak zgody na nagrywanie sesji psychoterapeutycznych.

Obraz Łozińskiego przypomina metodę kreacji wykorzystaną przez Krzysztofa Kieślowskiego w jego filmie Życiorys, w którym to główny bohater jest „zagrany” przez naturszczyka, a jego życiorys spreparowany na potrzeby filmu - wszystko jednak po to, by odsłonić mechanizm działania komisji partyjnej, a zatem dotrzeć do głębszej „prawdy”, której ukazanie byłoby niemożliwe przy wykorzystaniu narzędzi dokumentu obserwacyjnego. Film ten, będący pierwszym odejściem Kieślowskiego od realizmu w stronę inscenizacji, miał nakręcić w celach szkoleniowych dla członków partyjnych komisji, przed którą stawali członkowie PZPR, którzy złamali dyscyplinę partyjną. Stąd też skład komisji jest prawdziwy, a „życiorys” bohatera filmu powstał na podstawie kilkunastu teczek „oskarżonych”, gdyż Kieślowskiego dopuszczono do archiwum Komisji. Krzysztof Wierzbicki, bliski współpracownik Kieślowskiego, tak opisuje pracę nad filmem: „Józek [odtwórca głównej roli - przyp. A.Z.] dostał od Kieślowskiego swój wymyślony życiorys: szkoła kadetów, wojsko, praca w kopalni, zawodówka, praca w Zakładach Mechanicznych, życie prywatne, no i wreszcie „przewinienia”. Nasz bohater - w filmie nazywał się Antoni Gralak - zorganizował strajk na wydziale. Nie złożył donosu na kolegów, którzy pili spirytus fabryczny, w wyniku czego jeden z nich zmarł. Odmówił udziału w czynie partyjnym, czyli darmowej pracy w wolny dzień na rzecz miasta. Józek zapoznał się z życiorysem, ale nie wiedział, co jest w teczce, którą dysponowała Komisja. Z kolei Komisja nie 
znała życiorysu bohatera. (...) Tę teczkę spreparowałem na wzór autentycznych teczek, które znajdowały się w archiwum Komisji. (...) Wymyślony życiorys, podstawiony bohater, spreparowane dokumenty do tego stopnia sprowokowały Komisję, że efekt jej działania był prawdziwszy niż w rzeczywistości. Gdybyśmy filmowali prawdziwe obrady, z autentycznym podsądnym, nigdy nie zdobyliby się na takie sformułowania, jakie padały w tym udawanym procesie. Czy powstał film dokumentalny? Zostawiam to pytanie w zawieszeniu” (Wierzbicki, 2010).

Podobnie jak u Pawła Łozińskiego oglądając film Kieślowskiego widz nie ma świadomości, że ogląda rzeczywistość inscenizowaną, nie jest w żaden sposób o tym informowany w trakcie filmu. Napis wyjaśniający metodę pracy pojawia się u Łozińskiego na samym końcu i jest dla nieprzygotowanego widza zaskoczeniem, natomiast u Kieślowskiego inscenizacja nigdy nie jest ujawniona w obrębie samego dzieła, jedynie poprzez liczne wypowiedzi reżysera i współtwórców poznajemy kulisy pracy nad filmem.

Do tego nurtu nawiązuje również polska dokumentalistka Maria Zmarz-Koczanowicz, autorka m.in. filmu dokumentalnego Urzq̨d, którego inspiracją był m.in. Życiorys Kieślowskiego. W swoim eseju Zagadnienie inscenizacji fabularnej $w$ filmie dokumentalnym i metody dokumentalnej w filmie fabularnym stwierdziła, że „rzeczywistość filmową lepi się z fragmentów rzeczywistości zarejestrowanej, rzeczywistości przeżytej i rzeczywistości wyobrażonej” (Zmarz-Koczanowicz, 2012, s. 11-12). Według reżyserki rzeczywistość zarejestrowana powinna być maksymalnie obiektywna i zrealizowana z zachowaniem jedności miejsca i czasu, natomiast na nią nałożone są bardziej subiektywne „rzeczywistości” - wykreowana językiem filmowym, montażem, sposobem kadrowania (rzeczywistość przeżyta) oraz ta przefiltrowana przez wyobraźnię twórcy (rzeczywistość wyobrażona). „Widz wie, że ogląda świat umowny. Hierarchia i proporcje pomiędzy wspomnianymi elementami podporządkowane są temu, o czym robi się film. Co oznacza, że dla mnie film jest przede wszystkim filmem, a dopiero w drugiej kolejności »rodzajem filmowym« - dokumentem czy fabułą” (Zmarz-Koczanowicz, 2012, s. 12).

W filmie Urzq̨d reżyserka wykorzystała rzeczywiste wywiady z komornikami, a także zapisy audio ich interwencji u ubogich ludzi i odbierania mienia dłużnikom, których była świadkiem, ale postanowiła to wszystko osadzić w fikcyjnej warstwie wizualnej, zatrudniając do odegrania komorników siedzących w biurze zwykłych naturszczyków, nie mających z zawodem komornika nic wspólnego. Nie chodziło przy tym jedynie o ilustrowanie wypowiedzi bohaterów, lecz o stworzenie surrealistycznego klimatu oddającego nastrój urzędu. Wiele scen zostało również odtworzonych na podstawie zaobserwowanych przez reżyserkę sytuacji (jak scena 
jedzenia drugiego śniadania przez komorników przyjmujących petentów czy scena, w której biedna kobieta kładzie na stole gazetę, żeby komornik mógł położyć swoją teczkę nie narażając się na jej ubrudzenie). „Pracując nad tym filmem, nieustannie balansowaliśmy na granicy pomiędzy swobodnie rozumianą »inscenizacją« a »dokumentem«. Nie myśleliśmy o czystości gatunku, myśleliśmy o filmie i o tym, żeby najmocniej jak to możliwe uderzał w widza. Na jednym poziomie jest to więc film dokumentalny, a na innym fabularny” (Zmarz-Koczanowicz, 2012, s. 17).

Kieślowski, Zmarz-Koczanowicz i Paweł Łoziński swoje inscenizowane filmy stworzyli w oparciu o szczegółową dokumentację - dla Kieślowskiego była to lektura teczek członków PZPR stawianych przed komisją, dla Zmarz-Koczanowicz wielomiesięczne podglądanie pracy komorników, a dla Łozińskiego rozmowy z uczestnikami psychoterapii. Dzięki dokumentacji udało im się wykreować wiarygodne światy i pokazać głębszą prawdę o otaczającej nas rzeczywistości - głębszą niż ta możliwa do zarejestrowania jedynie metodą obserwacyjną.

Swój sposób postrzegania dokumentu Paweł Łoziński opisał kiedyś jako „własne spojrzenie na świat, historia prawdziwa, opowiedziana tak, że znaczy trochę więcej niż to, co widać w jej pierwszej warstwie. (...) Uważam, że dobrze skonstruowany film dokumentalny, idący w głąb tematu, widzowie przeżyją mocniej niż taki, który jest jak kolorowy wachlarz - otwiera się przed nami, potem zamyka i jest po wszystkim” (Mąka-Malatyńska, 2015, s. 684). Mając świadomość ograniczeń obserwacyjnej metody, współcześni twórcy filmów dokumentalnych coraz częściej decydują się na przekraczanie granic gatunkowych i tworzenie fabularno-dokumentalnych hybryd czy - posługując się terminem Oppenheimera „dokumentów wyobraźni”.

W wyreżyserowanej przeze mnie Królowej Ciszy również wykorzystałam stosowaną przez Oppenheimera metodę pracy. W dokumentalną warstwę opowiadającą o głuchoniemej romskiej dziewczynce z nielegalnego koczowiska zagrożonego eksmisją wplotłam inscenizowane sceny taneczne, tworząc rodzaj dokumentalnego musicalu. Fabularyzowane sceny stały się zatem niemalże „dokumentalnym” zapisem świata wewnętrznego głównej bohaterki, która pewnego dnia na śmietniku znajduje płyty DVD z filmami Bollywood i zafascynowana magicznym, kolorowym światem, odległym od tego, który ją otacza, sama zaczyna tańczyć. Ilekroć świat dookoła wydaje się wrogi, Denisa ucieka w bezpieczną przestrzeń wyobraźni. W trakcie realizacji filmu, tworząc dwie równoległe warstwy (stricte obserwacyjną, surową, dokumentalną oraz tę wykreowaną, baśniową), szukaliśmy punktów stycznych, rodzaju haków, na których można byłoby zawiesić sceny kreacyjne, fabularyzowane - jak choćby w scenie, gdy na teren romskiego koczowiska przyjeżdża policja z nakazem eksmisji, a dzieci zamieniają to smutne 
wydarzenie w zabawę z udziałem pistoletów zabawek. Łącząc te dwie warstwy, mogliśmy pokazać to, co w konwencji stricte dokumentalnej jest niemożliwe do pokazania - świat wewnętrzny bohatera, jego sposób odczuwania świata. Paradoksalnie więc sceny wykreowane miały charakter dokumentalny.

Jak słusznie zauważa Marek Hendrykowski „najwyższy czas skończyć z całkowicie anachronicznym na gruncie nowocześnie uprawianej nauki o filmie »szufladkowym « (segregacyjnym) pojmowaniem kategorii genologicznych. Zagadnienie rodzajów filmowych wymaga dzisiaj całkiem innego ich wymodelowania zarówno pod względem historii, jak i w odniesieniu do aktualnej współczesności” (Hendrykowski, 2012, s. 247).

\section{Bibliografia}

Cousins, M., McDonald, K. (1996). Imagining Reality: The Faber Book of Documentary. London: Faber and Faber.

Hendrykowski, M. (2005). Klucze do rzeczywistości. Szkice i rozmowy o polskim filmie dokumentalnym po roku 1989. Poznań: Wydawnictwo Naukowe Uniwersytetu im. Adama Mickiewicza.

Hendrykowski, M. (2012). Dokument - fikcja - realizm. W: M. Jazdon, K. Mąka-Malatyńska, P. Pławuszewski (red.), Pogranicza dokumentu. Poznań: Centrum Kultury Zamek.

Hendrykowski, M. (1995). Słownik pojęć filmowych. Poznań: Ars Nova.

Łoziński, M. (2015). Potrząsanie akwarium. W: Nowy Folder, Magazyn Reporterów i Dziennikarzy Centrum Badań i Edukacji im. Ryszarda Kapuścińskiego. Pobrane z: http://www.nowyfolder.com/potrzasanie-akwarium/.

Mąka-Malatyńska, K. (2015). Polska szkoła dokumentu - żywa tradycja polskiego kina. W: M. Hendrykowska (red.), Historia polskiego filmu dokumentalnego (1945-2014). Poznań: Wydawnictwo Naukowe UAM.

Morin, E. (1977). Kino i wyobraźnia. Warszawa: Państwowy Instytut Wydawniczy.

Przylipiak, M. (2004). Poetyka kina dokumentalnego. Gdańsk: Wydawnictwo Uniwersytetu Wrocławskiego.

Rotha, P. (1952). Documentary film. Londyn: Faber and Faber.

Wierzbicki, K. (2010). Kieślowski w PZPR. Gazeta Wyborcza, 13.

Zmarz-Koczanowicz, M. (2012). Zagadnienie inscenizacji fabularnej w filmie dokumentalnym i metody dokumentalnej w filmie fabularnym na przykładzie dwóch zrealizowanych przeze mnie filmów: fabularnego Kraju świata i dokumentalnego Urzędu. W: M. Jazdon, K. Mąka-Malatyńska, P. Pławuszewski, P. (red.), Pogranicza dokumentu. Poznań: Centrum Kultury Zamek. 